\title{
The Sustainability Approach to Treatment of DR-TB Patients through Community Social Organization (Aisyiyah)
}

\author{
Tutik Kusmiati* (D), Catur Agustiyanto, Vicky Reinold Rampengan and \\ Soedarsono \\ Department of Pulmonology and Respiratory Medicine, Faculty of Medicine, Universitas Airlangga - Dr. \\ Soetomo General Academic Hospital, Surabaya, Indonesia.
}

\begin{abstract}
Multidrug-resistant tuberculosis (MDR-TB) is currently an important public health problem in the world. Treatment of MDR-TB patients takes a long time, 20-24 months in standard regimen or 9-11 months in shorter regimen. Long treatment duration and drug toxicities which higher than drug-sensitive TB can cause drop out of treatment. Aisyiyah is a community social organization which provide assistance to TB patients in order to complete the treatment within specified time period. This study aimed to compare the outcome of DR-TB patients assisted by Aisyiyah and those who did not. A retrospective study was conducted Dr. Soetomo General Academic Hospital, Surabaya, Indonesia. Data was taken from DR-TB patients medical record since October 2014 until December 2017. There were 434 MDR-TB patients in the period of October 2014 to December 2017, with 75 patients (17.28\%) received assistance from Aisyiyah. The average age was $44.38 \pm 12.28$ years old. Comparison between those who were assisted and not, from the male sex $(49.3 \%$ vs $60.2 \%)$, women $(50.7 \%$ vs $39.8 \%)$; based on resistance pattern: (5.3\% vs $10.3 \%)$ from MDR TB, $(85.3 \%$ vs $75.5 \%)$ from RR, (2.7\% vs $8.1 \%)$ from XDR; Outcome obtained: Cure (1.6\% vs $15.0 \% ; p=0,031)$, Treatment completion $(0.0 \%$ vs $0.5 \% ; p=0,517)$, Default ( $2.8 \%$ vs $28.3 \% ; p=0,002)$; Failed $(0.2 \%$ vs $1.6 \% ; p=0,718)$; Death ( $1.6 \%$ vs $7.9 \% ; p=0,965)$. There were significant correlations between cure and default outcome in DR-TB patients accompanied by Aisyiyah compared to those not accompanied.
\end{abstract}

Keyword: Outcome therapy, DR-TB, Community Social Organization

*Correspondence: drtutikkusmiati2018@gmail.com; tut.kusmiati@gmail.com

(Received: March 16, 2020; accepted: September 23, 2020)

Citation: Kusmiati T, Agustiyanto C, Rampengan VR, Soedarsono. The Sustainability Approach to Treatment of DR-TB Patients through Community Social Organization (Aisyiyah). J Pure Appl Microbiol. 2020;14(4):2477-2481. doi: 10.22207/JPAM.14.4.25

(C) The Author(s) 2020. Open Access. This article is distributed under the terms of the Creative Commons Attribution 4.0 International License which permits unrestricted use, sharing, distribution, and reproduction in any medium, provided you give appropriate credit to the original author(s) and the source, provide a link to the Creative Commons license, and indicate if changes were made. 


\section{INTRODUCTION}

Worldwide, tuberculosis (TB) is one of the top 10 causes of death, and the leading cause from a single infectious agent (above HIV/AIDS); millions of people continue to fall sick with the disease each year, In 2017, TB caused an estimated 1.3 million deaths, TB affects all countries and all age groups, but overall the best estimates for 2017 were that $90 \%$ of cases were adults (aged $\geq 15$ years), $64 \%$ were male ${ }^{1}$.

TB is an infectious disease that causes many deaths in Indonesia. In 2016, there were 274 deaths per day in Indonesia. The new TB case has reached $1,020,000$ people. That number makes Indonesia ranked third in the highest TB cases in the world after India. Then, followed by China, the Philippines, Pakistan, Nigeria and southern Africa ${ }^{2,3}$.

Multidrugs resistant tuberculosis (MDRTB) or multiple resistant tuberculosis is currently an important public health problem in the world both in terms of morbidity and mortality. In 2011 it was estimated that worldwide the prevalence of MDR-TB was around $3.8 \%$ of new tuberculosis (TB) cases and about $20 \%$ of TB cases with a previous history of treatment. Approximately $60 \%$ of MDR-TB cases globally are in China, India and Russia $^{3}$. The MDR-TB case in Indonesia is estimated to be around 6100 cases each year. The highest percentage of MDR-TB cases was found in Eastern European and Central Asian countries with MDRTB percentages of $9-32 \%$ of new TB cases and $50 \%$ of TB cases with a previous history of treatment ${ }^{4}$.

One of the challenges in the management of drug resistant TB is an increase in the number of cases of patients dropping out each year. This is due to the relatively long treatment of drugresistant TB (20-24 months) accompanied by various side effects felt by patients 5 . In 2016, WHO issued recommendations for the use of shortterm alloys (9-11 months) for drug-resistant TB patients. The recommendation is based on the results of research in several countries that have used a mixture of short-term treatments, have satisfactory treatment success rates ${ }^{1,6,7}$.

Prevention of MDR-TB is carried out through internationally recommended strategies, in short-term direct treatment (DOTS) and proven effective and cost-effective, although in some cases failure to cure ${ }^{8,9}$. With assistance is very influential in MDR-TB treatment, given that XDR$T B$ is a dangerous disease for the community, it is likely that the patient will recover and be appropriate if accompanied by assistance ${ }^{8,10}$.

Aisyiyah is a Muhammadiyah Women's organization founded in Yogyakarta on May 19, 1917 by Nyai Ahmad Dahlan. Towards the age of a century, Aisyiyah who is a component of the women's union Muhammadiyah has provided social, educational, health, and religious services that have been the starting point of her movement ${ }^{11}$. One of the work programs is to monitor patients who are undergoing DR-TB treatment. In Surabaya, Aisyiyah social organizations that carry out mentoring began in November 2014, but only took place in December 2019.

\section{METHODS}

\section{Study design}

This was a retrospective study that conducted at Dr. Soetomo General Academic Hospital, Surabaya, Indonesia.

\section{Study population}

Population study were 434 DR-TB patients in the period of October 2014 to December 2017, with 75 patients received assistance from Aisyah. Diagnosis of DR-TB patients according to national TB control guidelines. DR-TB patients are divided into 4 groups based on rapid tests (Gene Experts) and drug sensitivity tests such as RR, MR, MDR TB, Pre XDR TB, and XDR TB.

\section{Data collection}

Data were taken from the patient's medical record between October 2014-December 2017. The data consisted of age, gender, culture test, gene expert, drug sensitivity test, and the outcome. The outcome divided into 6 groups such as cure, complete treatment, lost to follow up/ default, failure treatment, death, and on treatmet.

\section{RESULTS}

There were 434 DR-TB patients in the period of October 2014 to December 2017, with 75 patients $(17.28 \%)$ received assistance from Aisyah. The average agewas $44.38 \pm 12.28$ years old. Comparison between those who were assisted and not, from the male sex ( $49.3 \%$ vs $60.2 \%)$, women $(50.7 \%$ vs $39.8 \%)$; Based on resistance pattern: (5.3\% vs $10.3 \%)$ from MDR TB, $(85.3 \%$ 
vs $75.5 \%)$ from RR, (2.7\% vs $8.1 \%)$ from XDR; Outcome obtained: Cure $(1.6 \%$ vs $15.0 \% ; p=$ $0.031)$, Treatment completion $(0.0 \%$ vs $0.5 \%$; $p=$ 0.517 ), Default ( $2.8 \%$ vs $28.3 \%$; $p=0.002$ ); Failed $(0.2 \%$ vs $1.6 \% ; p=0.718)$; Death $(1.6 \%$ vs $7.9 \% ; p$ $=0.965$; table 2 and 3 ).

Demography of DR-TB patients in the period of October 2014 to December 2017. The results showed that most of the patients who were assisted were women (50.7\%). However, in patients who were not assisted, the majority of men (60.2\%). The average agewas $44.38 \pm 12.28$ years old. Diagnosis DR-TB patients in the period of October 2014 to December 2017data seen from diagnosis, Comparison between those who were assisted and not, from based on resistance pattern more diagnosed as TB RR (Table 2).

Comparison between those who were assisted and not, from outcome obtained: Cure (1.6\% vs $15.0 \% ; p=0.031)$, this indicates the influence between people who were assisted and not in undergoing treatment with cured results. Comparison between those who were assisted and not, from outcome obtained: Treatment completion $(0.0 \%$ vs $0.5 \% ; p=0,517)$, this indicates there is no influence between people who are

Table 1. Definitions of TB Treatment Outcome at DR-TB Patients

\begin{tabular}{|c|c|}
\hline Terms & Definition \\
\hline Cured & $\begin{array}{l}\text { DR-TB patients with positive result of bacteriology data at the first treatment then become negative } \\
\text { result of bacteriology data in the end of the treatment and at the previous bacteriology test. }\end{array}$ \\
\hline $\begin{array}{l}\text { Completed } \\
\text { Treatment }\end{array}$ & $\begin{array}{l}\text { DR-TB patients who complete the treatment and the bacteriology data before the end of the } \\
\text { treatment is negative but there is no bacteriology data at the end of the treatment. }\end{array}$ \\
\hline $\begin{array}{l}\text { Lost to Follow } \\
\text { Up / Default }\end{array}$ & $\begin{array}{l}\text { DR-TB patients that have not started the treatment or stop the treatment continuously during } 2 \\
\text { months or more. }\end{array}$ \\
\hline $\begin{array}{l}\text { Treatment } \\
\text { Failed }\end{array}$ & $\begin{array}{l}\text { DR-TB patients who have positive result of bacteriology data until the end of the treatment or } \\
\text { the result of bacteriology data become positive after fifth month or more during the treatment, } \\
\text { or whenever during the treatment showed that there are drug resistant based on laboratory tests. }\end{array}$ \\
\hline Died & DR-TB patients that died because of any reasons before start the treatment or during the treatment \\
\hline On Treatment & Patients who are still undergoing treatment. \\
\hline
\end{tabular}

Table 3. Treatment outcome in DR-TB patients

Table 2. Demography of DR-TB patients

\begin{tabular}{lll}
\hline & $\begin{array}{l}\text { Not Assisted } \\
(\mathrm{n}=359 ; \%)\end{array}$ & $\begin{array}{l}\text { Assisted } \\
(\mathrm{n}=75 ; \%)\end{array}$ \\
\hline $\begin{array}{l}\text { Gender } \\
\text { Male }\end{array}$ & $216(60.2)$ & $37(49.3)$ \\
Female & $143(39.8)$ & $38(50.7)$ \\
Age & & $14(18.7)$ \\
$<30$ years old & $49(13.6)$ & $19(25.3)$ \\
$30-40$ years old & $74(20.6)$ & $22(29.3)$ \\
$41-50$ years old & $107(29.8)$ & $15(20.0)$ \\
$51-60$ years old & $97(27.0)$ & $5(6.7)$ \\
$>60$ years old & $32(8.9)$ & $2(2.7)$ \\
Diagnosis DR-TB & & $3(4.0)$ \\
XDR & $29(8.1)$ & $4(5.3)$ \\
Pre-XDR & $13(3.6)$ & $64(85.3)$ \\
MDR & $37(10.3)$ & $2(2.7)$ \\
RR & $271(75.5)$ & \\
MR & $9(2.5)$ & \\
& &
\end{tabular}

\begin{tabular}{llll}
\hline & $\begin{array}{l}\text { Not Assisted } \\
(n=359 ; \%)\end{array}$ & $\begin{array}{l}\text { Assisted } \\
(\mathrm{n}=75 ; \%)\end{array}$ & $\mathrm{p}$ \\
\hline $\begin{array}{c}\text { Cure } \\
\text { Yes }\end{array}$ & $65(18.1)$ & $6(8.0)$ & $0.031^{*}$ \\
$\quad$ No & $294(81.9)$ & $69(92.0)$ & \\
$\begin{array}{c}\text { Treatment } \\
\text { Complete }\end{array}$ & $2(0.6)$ & $0(0.0)$ & 0.517 \\
$\quad$ No complete & $357(99.4)$ & $75(100.0)$ & \\
$\begin{array}{c}\text { Outcome } \\
\text { Default }\end{array}$ & $123(34.3)$ & $12(16.0)$ & $0.002^{*}$ \\
$\quad$ No Default & $236(65.7)$ & $63(84.0)$ & \\
$\begin{array}{c}\text { Death } \\
\text { Yes }\end{array}$ & $34(9.5)$ & $7(9.3)$ & 0.965 \\
$\quad$ No & $325(90.5)$ & $68(90.7)$ & \\
$\begin{array}{c}\text { Failed } \\
\text { Yes }\end{array}$ & $7(2.0)$ & $1(1.3)$ & 0.718 \\
$\quad$ No & $352(98.0)$ & $74(98.7)$ & \\
On Treatment & & & \\
Yes & $128(35.7)$ & $49(65.3)$ & $0.000^{* *}$ \\
No & $231(64.3)$ & $26(34.7)$ & \\
\hline & & www.microbiologyjournal.org
\end{tabular}


assisted and not in undergoing treatment with complete treatment results. Comparison between those who were assisted and not, from outcome obtained:Default ( $2.8 \%$ vs $28.3 \%$; $p=0.002)$, this indicates the influence between people who were assisted and not in undergoing treatment with default results.

Comparison between those who were assisted and not, from Outcome obtained: Failed $(0.2 \%$ vs $1.6 \% ; p=0.718)$, this indicates there is no influence between people who are assisted and not in undergoing treatment with failed results. Comparison between those who were assisted and not, from Outcome obtained. Death (1.6\% vs $7.9 \% ; p=0.965)$, this indicates there is no influence between people who are assisted and not in undergoing treatment with death results. Comparison between those who were assisted and not, from Outcome obtained: On Treatment (11.3\% vs 7.9\%; $p<0.001$; Table 3 ).

\section{DISCUSSION}

DR-TB treatment does require a period of at least 9 months plus more drug side effects that occur after the patient has taken the drug, the amount of medicine that must be taken a $\operatorname{lot}^{4}$, so assistance here is very much needed to support the continuity of taking medicine, mentoring can be done by the closest person, family, by someone else $^{11}$.

Aisyah is a social organization whose work program is to supervise people who are running DR-TB treatment, they have specific criteria for those who will be accompanied, one of them is a poor family, a family that lives alone or does not have a close family, besides accompanying aisyiyah, it also helps to meet food needs for the patient she is accompanying ${ }^{12}$.

From the results of the study, people who were accompanied by Aisyiyah were very influential to get cured results, but there were also those who were influential but with default results, this could be due to all patients who received assistance from Aisyah many patients who were old, lacking support from the environment, and there is less attention from the family.

This can be investigated further to find out the exact reason why people who are taking DR-TB who have received assistance can still have a default result. It is expected that with the assistance of patients can be more obedient in care and complete care.

\section{CONCLUSION}

There were significant correlations between cure and default outcome in DR-TB patients accompanied by Aisyah compared to those not accompanied.

\section{ACKNOWLEDGMENTS}

We appreciate all Staff of Dr. Soetomo General Hospital, Department of Pulmonology and Respiration Medicine, Faculty of Medicine Universitas Airlangga, Surabaya, Indonesia, Community social organization Aisyiyah, Sidoarjo, Indonesia, Appreciation also goes to the entire staff of Laboratory Department and DOTS unit of Dr. Soetomo General Academic Hospital, Surabaya, Indonesia. We would like to express our sincere thanks to the Indonesia Tuberculosis International Meeting (INATIME) event which facilitated us to present this research on 5-7 April 2019 at Surabaya, Indonesia.

\section{CONFLICT OF INTEREST}

The authors declare that there is no conflict of interest.

\section{AUTHORS' CONTRIBUTION}

All authors contributed toward data analysis, drafting and revising the paper, gave final approval of the version to be published and agree to be accountable for all aspects of the work.

\section{FUNDING}

None.

\section{ETHICS STATEMENT}

All procedures performed in studies involving human participants were in accordance with the ethical standards of the Ethics Committee in Dr. Soetomo General Academic Hospital, Surabaya, Indonesia.

\section{DATA AVAILABILITY}

The data set used and/or analyzed during the current study are available from corresponding author on reasonable request. 


\section{REFERENCES}

1. WHO. Global tuberculosis report 2018. Geneva: World Health Organization; 2018. Licence: CC BY-NC-SA 3.0 IGO. WHO/CDS/TB/2018.20. Available from: http:// apps. who. int/iris/bitstream ...

2. Seung KJ, Keshavjee S, Rich ML. MultidrugResistant Tuberculosis and Extensively DrugResistant Tuberculosis. Cold Spring Harb Perspect Med. 2015;5(9):a017863-a017863. doi: 10.1101/ cshperspect.a017863

3. Kusnanto P, Eko V, Pakiding H, Nurwidiasih D. Multidrug resistant tuberculosis (MDR-TB): tinjauan epidemiologi dan faktor risiko efek samping obat anti tuberkulosis. Majalah Kedokteran Bandung. 2014;46(4):189-196. doi: 10.15395/mkb.v46n4.336

4. Mukherjee A, Lodha R, Kabra SK. Current therapies for the treatment of multidrugresistant tuberculosis in children in India. Expert Opin Pharmacother. 2017;18(15):1595-1606. doi: 10.1080/14656566.2017.1373090

5. WHO. WHO treatment guidelines for multidrug-and rifampicin-resistant tuberculosis. Geneva $(\mathrm{CH})$ : World Health Organization. 2018.

6. Depkes R. Panduan pelayanan antenatal. Jakarta:
Depkes RI. 2008.

7. Falzon D, Schunemann HJ, Harausz E, et al. World Health Organization treatment guidelines for drugresistant tuberculosis, 2016 update. Eur Respir J. 2017;49(3):1602308. doi: 10.1183/13993003.023082016

8. Asri SDA. Masalah Tuberkulosis Resisten Obat. Universitas Islam Negeri Syarif Hidayatullah, Jakarta Indonesia. 2014;41(4).

9. WHO, Health Pi. Management of MDR-TB: A Field Guide, a Companion Document to Guidelines for the Programmatic Management of Drug-Resistant Tuberculosis. World Health Organization. 2009.

10. Rabahi MF, Silva Junior JLRd, Ferreira ACG, TannusSilva DGS, Conde MB. Tuberculosis treatment. J Bras Pneumol. 2017;43(6):472-486. doi: 10.1590/s180637562016000000388

11. Sormin D. Program 'Aisyiyah Dalam Mewujudkan Keluarga Sakinah Menuju Islam Berkemajuan. Intiqad: Jurnal Agama dan Pendidikan Islam. 2019;11(1):155170. doi: 10.30596/intiqad.v11i1.3142

12. Samari G, Alcala HE, Sharif MZ. Islamophobia, Health, and Public Health: A Systematic Literature Review. Am J Public Health. 2018;108(6):e1-e9. doi: 10.2105/ AJPH.2018.304402 